\title{
PERANAN PUPUK DAN FUNGISIDA TERHADAP PEMULIHAN TAJUK AKIBAT PENYAKIT GUGUR DAUN PESTALOTIOPSIS PADA KLON GT 1 DI KEBUN PERCOBAAN PUSAT PENELITIAN KARET SEMBAWA
}

\author{
The Role of Fertilizer and Fungicide to Rubber Plant Canopy Recovery Due to \\ Pestalotiopsis Leaf Fall Disease on GT 1 Clone at Experimental Garden \\ Indonesian Rubber Research Institute Sembawa
}

Tri Rapani FEBBIYANTI*, Charlos Togi STEVANUS, dan Radite TISTAMA

Pusat Penelitian Karet

Jln Raya Palembang - Pangkalan Balai KM 29

Sembawa Banyuasin 30593 Sumatera Selatan

*Email : trifebbi@yahoo.com

Diterima : 15 Juli 2020 / Disetujui : 25 Juli 2020

\begin{abstract}
Pestalotiopsis leaf fall disease (PLFD) has become an outbreak with affected area in Indonesia reached 382,000 ha in 2019. As a result, the decline in rubber production was more than 30\%. To date, effective methods for controlling this disease have not been reported, disease control effort can be done by increasing the plant's defense system and reducing the amount of inoculum in the plantation. This study aims to determine the effect of fertilizer and fungicide applications to the canopy density and increased yield in GT 1 clones affected by Pestalotiopsis leaf fall diseases in Experimental Garden in Sembawa, Indonesian Rubber Research Institute. Compared to controls, 100\% fertilizer recommended dosage increased canopy density by $4 \%$ with an increase in production of $3 \mathrm{gr}$ drc/tree/tapping. The addition of $25 \%$ extra Nitrogen and extra Potassium can trigged canopy density 5\% and $6 \%$ respectively with an increased in production of 5 and $6 \mathrm{gr}$ drc/tree/tapping. Canopy density was shown to increase both by blanket spraying fungicides in ground cover and fogging on young leaves respectively $9 \%$ and foowed by increases in production $5 \mathrm{gr}$ drc/tree/tapping. The application of blanket fungicides spraying on ground cover and fogging can maintain the better of canopy and dry rubber yield.
\end{abstract}

Keywords : Fertilizer; fungicide; leaf fall disease; Pestalotiopsis; rubber

\begin{abstract}
Abstrak
Penyakit gugur daun Pestalotiopsis (PGDP) mengalami outbreak dengan luas serangan di Indonesia mencapai 382.000 ha pada tahun 2019. Akibatnya, penurunan produksi karet lebih dari 30\%. Hingga saat ini, cara yang efektif untuk pengendalian penyakit ini belum dilaporkan. Upaya pengendalian penyakit dapat dilakukan dengan meningkatkan sistem pertahanan tanaman dan menekan jumlah inokulum di perkebunan. Penelitian ini bertujuan untuk mengetahui pengaruh aplikasi pupuk dan fungisida terhadap kerapatan tajuk dan penambahan produksi pada klon GT 1 yang terserang PGD Pestalotiopsis. Dibandingkan kontrol, pemupukan 100\% dosis rekomendasi meningkatkan kerapatan tajuk 4\% dengan kenaikan produksi 3 g/p/s. Pemberian ekstra 25\% Nitrogen dan ekstra Kalium dapat memicu kerapatan tajuk berturut-turut $5 \%$ dan $6 \%$ dengan kenaikan produksi 5 dan 6 g/p/s. Kerapatan tajuk terbukti meningkat baik dengan penyemprotan fungisida di gawangan maupun pengasapan pada daun muda masing-masing 9\%, dan diiringi kenaikan produksi berturut-turut $5 \mathrm{~g} / \mathrm{p} / \mathrm{s}$. Kombinasi aplikasi pupuk ektra 25\% N, K dan fungisida pada gawangan dan fogging memberikan kerapatan tajuk 9\% dan kenaikan produksi $10 \mathrm{~g} / \mathrm{p} / \mathrm{s}$. Pemupukan berperan dalam meningkatkan tajuk dan produksi. Aplikasi fungisida di gawangan dan fogging dapat mempertahankan tajuk lebih baik dan produksi karet kering.
\end{abstract}


Kata kunci: Fungisida; karet; penyakit gugur daun; Pestalotiopsis; pupuk

\section{PENDAHULUAN}

Penyakit gugur daun Pestalotiopsis (PGDP) pertama kali terdeteksi di Indonesia tahun 2016 di wilayah Sumatera Utara, kemudian menyebar ke Sumatera Selatan akhir tahun 2017 dan terus menjadi outbreak sampai saat ini. Penyakit ini mengakibatkan penurunan produksi karet lebih dari 30\%. Gejala serangan mulai muncul pada daun tua secara sporadis menimbulkan nekrosis berbentuk bulat dan akhirnya gugur. Data Direktorat Jenderal Perkebunan [Dirjebun] pada tahun 2019, menunjukkan bahwa luas serangan penyakit ini di Indonesia sudah mencapai 382.000 Ha meliputi wilayah Sumut, Sumbar, Riau, Jambi, Sumsel, Babel, Bengkulu, Lampung, Jawa Barat, Jawa Tengah, Kalsel, Kalbar dan Sulteng. Penyakit gugur daun ini merupakan penyakit tular udara yang penyebarannya sangat cepat dan mengakibatkan pengguguran daun secara terus menerus (Febbiyanti \& Fairuzah, 2019).

Beberapa spesies Pestalotiopsis dilaporkan sebagai patogen oportunistik yang menyerang tanaman pada saat tanaman dalam kondisi stres (Hu et al., 2007; Maharachchikumbura et al., 2012) dan dapat juga bersifat safrofit memanfaatkan daun mati, kulit kayu dan ranting (Maharachchikumbura et al., 2011; Maharachchikumbura et al., 2014). Pestalotiopsis juga dilaporkan menyebabkan hilangnya hasil yang signifikan secara ekonomi pada tanaman hortikultura seperti kelapa, jahe, apel, jambu biji, mangga, blueberry, kastanye, selentingan, kemiri, lengkeng, anggrek, persik, rambutan dan teh (Espinoza et al., 2008; Valencia et al., 2011; Gonzalez et al., 2012; Maharachchikumbura etal., 2014; Chamorro et al., 2016).

Strategi pengendalian penyakit gugur daun umumnya diarahkan pada penggunaan klon resisten dan induksi sistem pertahanan tanaman. Hingga saat ini belum ditemukan klon karet yang benarbenar toleran terhadap penyakit tersebut. Sedikit informasi berdasarkan pengamatan di beberapa kebun, klon RRIC 100 menunjukkan toleransi yang lebih baik dibandingkan klon-klon karet lain. Klonklon karet di areal perkebunan karet dengan pemupukan standar menunjukkan gejala serangan yang lebih sedikit dibandingkan kebun karet yang tidak memupuk sama sekali. Dalam ulasannya, Dordas (2009) membahas peranan unsur hara dalam perlindungan tanaman melalui peningkatan pertumbuhan tanaman, dan menginduksi proses fisiologis sehingga tanaman lebih toleran terhadap serangan penyakit.

Pemberian pupuk organik dan anorganik berpengaruh signifikan terhadap penurunan intensitas penyakit layu pada kacang tanah yang disebabkan oleh Sclerotium rolfsi (Kalay et al., 2017), pemupukan juga memberikan pengaruh positif dalam menekan serangan penyakit budok tanaman nilam yang disebabkan oleh Synchytrium pogostemonis (Kusnanta 2005; Wahyuno 2010; Burhanudin \& Nurmansyah 2012). Pemberian pupuk NPK pada tanaman padi juga mampu menurunkan intensitas serangan penyakit bercak daun cokelat dari $57,81 \%$ menjadi $32,05 \%$ dan penyakit bercak bergaris dari $8,55 \%$ menjadi 2,48\% (Abdulrachman, 2001), sedangkan pemberian pupuk K menekan serangan penyakit hawar daun 20$30 \%$ dibanding tanpa pemberian pupuk $\mathrm{K}$ (Suryadi 1995). Pada varietas yang rentan terhadap penyakit blas, penggunaan dosis pupuk yang sesuai rekomendasi dapat menurunkan persentase serangan penyakit blas (Bhat et al. 2013).

Pada pengujian awal, penggunaan pupuk dikombinasikan dengan fungisida dapat mengurangi tingkat keparahan penyakit Pestalotiopsis pada tanaman karet. Nutrisi dapat menghambat perkembangan penyakit melalui perubahan fisiologi tanaman maupun patogen penyakit atau keduanya. Nutrisi pada tanaman dapat memengaruhi biokimia dan integritas dinding sel, menekan kerusakan membran, atau menekan komposisi metabolit inang seperti konsentrasi fenolik pada tanaman (Dordas, 2009). Penggunaan pupuk dalam pengendalian penyakit karet memberikan banyak keuntungan, terutama dalam mempertahankan produksi karet (Wijaya et al. 2014). Biaya, tenaga dan waktu yang 
diperlukan menjadi lebih hemat atau 2-3 kali lebih murah dibandingkan dengan penggunaan fungisida. Selain menghemat biaya, tenaga dan waktu pengendalian, pemberian pupuk juga akan mem engaruhi peningkatan pertumbuhan dan produksi tanaman. Mengingat intensitas serangan Pestalotiopsis yang tinggi dan sangat luas maka perlu dilakukan pengujian kombinasi pemupukan dan aplikasi fungsida dalam pengendalian penyakit ini.

Penelitian dilaksanakan di kebun Percobaan Pusat Penelitian Karet Sembawa pada klon GT 1 karena klon GT 1 merupakan salah satu klon yang rentan terhadap penyakit gugur daun Pestalotiopis, dan penelitian bertujuan untuk mengetahui pengaruh aplikasi pupuk dan fungisida terhadap kerapatan tajuk dan penambahan produksi pada klon GT 1 yang terserang PGDP di Kebun Percobaan Pusat Penelitian Karet Sembawa, Kabupaten Banyuasin Sumatera Selatan

\section{BAHAN DAN METODE}

Penelitian pengendalian Pestalotiopsis terdiri dari 7 perlakuan yaitu P0) tanpa pemupukan dan aplikasi fungisida (kontrol), (P1) pemupukan 100\% dosis rekomendasi atau dosis 100\% NPKMg , P2) pemupukan $100 \%$ rekomendasi dengan ekstra 25\% Nitrogen (N), P3) pemupukan
$100 \%$ dosis rekomendasi dengan ekstra 25\% Kalium (K), P3) Penyemprotan fungisida pada gawangan, P4) aplikasi fungisida dengan cara fogging, P5) Semprot fungisida pada gawangan dan fogging, P6) pemupukan $100 \%$ dosis rekomendasi dengan ekstra $\mathrm{N}+\mathrm{K}+$, sekaligus penyemprotan fungisida pada gawangan dan fogging. Data dosis pupuk dan fungisida disajikan pada Tabel 1. Plot penelitian terletak di Divisi 1 Kebun Percobaan Puslit Karet Sembawa, jenis klon GT 1, tahun tanam 2011. Setiap plot perlakuan terdiri dari 250 pohon, diulang 2 kali, dengan total luas areal penelitian ini \pm 7 Ha.

Aplikasi fungisida dengan cara fogging menggunakan bahan aktif heksakonazol yang dicampur dengan minyak mineral. Pengabutan memakai alat Full Fog K 20 atau alat fogger. Fogging dilaksanakan pada dini hari sekitar jam 02.00-05.00 dengan memanfaatkan embun di daun dan kondisi angin tenang. Aplikasi fungisida pada gawangan menggunakan knapsack sprayer dengan target serasah daun yang gugur terkena Pestalotiopsis. Penelitian disusun menggunakan Rancangan Acak Kelompok dan uji lanjut menggunakan DMRT (Uji Duncan) taraf 5\%. Penelitian dimulai Juni 2018 sampai April 2020. Aplikasi pupuk tahun 2018 dilaksanakan 1 kali di semester II, 20192 kali di semester I dan II, dan 2020 baru dilaksanakan 1 kali di semester I.

Tabel 1. Dosis pupuk pada masing-masing perlakuan

Table 1. Dosage of fertilizer at each treatment

\begin{tabular}{|c|c|c|}
\hline $\begin{array}{l}\text { Pupuk } \\
\text { Fertilizer }\end{array}$ & $\begin{array}{l}\text { Jenis } \\
\text { Type }\end{array}$ & $\begin{array}{c}\text { Dosis pupuk } \\
\text { (g/phn/tahun } / 2 \times \text { aplikasi) } \\
\text { Dosage of fertilizer } \\
\text { (g/t/y/2x application) }\end{array}$ \\
\hline Perlakuan $\mathrm{PO}=$ kontrol & Tanpa pupuk dan fungisida & - \\
\hline $\begin{array}{l}\text { Perlakuan } \mathrm{P} 1=\text { dosis } 100 \% \\
\text { rekomendasi }\end{array}$ & $\begin{array}{l}\mathrm{N} \text { (urea) } \\
\mathrm{P} \text { (TSP) } \\
\mathrm{K} \text { (KCl) } \\
\text { Kieserit } \\
\text { jumlah }\end{array}$ & $\begin{array}{c}350 \\
300 \\
250 \\
79 \\
979\end{array}$ \\
\hline $\begin{array}{l}\text { Perlakuan P2 = dosis pupuk } \\
100 \%+\text { ekstra } 25 \% \mathrm{~N}\end{array}$ & $\begin{array}{l}\text { extra } 25 \% \mathrm{~N} \\
\text { dosis } 100 \%+\text { ekstra } \mathrm{N}\end{array}$ & $\begin{array}{c}175 \\
1154\end{array}$ \\
\hline $\begin{array}{l}\text { perlakuan p3 = dosis pupuk } \\
100 \%+\text { ekstra } 25 \% \mathrm{~K}\end{array}$ & $\begin{array}{l}\text { extra } 25 \% \mathrm{~K} \\
\text { dosis } 100 \%+\text { ekstra } \mathrm{K}\end{array}$ & $\begin{array}{c}125 \\
1279\end{array}$ \\
\hline
\end{tabular}


Tabel 2. Dosis fungisida pada masing-masing perlakuan Table 2. Dosage of fungicide at each treatment

\begin{tabular}{|c|c|c|}
\hline $\begin{array}{l}\text { Fungisida } \\
\text { Fungicide }\end{array}$ & $\begin{array}{l}\text { Jenis } \\
\text { Type }\end{array}$ & $\begin{array}{c}\text { Dosis bahan } \\
\text { (/liter/Ha/aplikasi) } \\
\text { Dosage } \\
\text { (/liter/Ha/application) }\end{array}$ \\
\hline $\begin{array}{l}\text { perlakuan } \mathrm{p} 4=\text { dosis pupuk } \\
100 \%+\text { fungisida pada } \\
\text { gawangan }\end{array}$ & $\begin{array}{l}\text { Thiopanatmethil ( } 2 \\
\text { cc/liter larutan)(1 ha } \\
=\text { butuh } 500 \text { liter } \\
\text { larutan })\end{array}$ & 1 \\
\hline $\begin{array}{l}\text { perlakuan p5 = dosis pupuk } \\
100 \%+\text { fogging }\end{array}$ & $\begin{array}{l}\text { Heksakonazol } \\
\text { solar } \\
\text { Emulgator }\end{array}$ & $\begin{array}{c}0,25 \\
2 \\
0,05 \\
\end{array}$ \\
\hline $\begin{array}{l}\text { Perlakuan p6 = dosis pupuk } \\
100 \%+\text { ektra } 25 \% \mathrm{~N}, \mathrm{~K}+ \\
\text { aplikasi fungisida pada } \\
\text { gawangan dan fogging }\end{array}$ & \multicolumn{2}{|c|}{ semua komponen } \\
\hline
\end{tabular}

Parameter pengamatan yang dilakukan diantaranya :

\section{Kerapatan Tajuk (\%)}

Kerapatan tajuk diukur berdasarkan kategori yang dikeluarkan oleh International Rubber Research and Development Board (IRRDB) (Gambar 1). Pengukuran secara manual dengan cara mengamati persentase kerapatan tajuk dan pengambilan foto dari kamera yang dipasang pada alat drone. Foto-foto yang diperoleh kemudian dibaca dengan software canopy app. Jumlah daun yang gugur pada setiap perlakuan dimonitor dengan perangkap daun, berupa jaring berbentuk petakan berukuran $1 \mathrm{~m}$ persegi yang dipasang di gawangan karet. Jumlah daun yang jatuh tersebut dihitung total selama 1 bulan.

\section{Index for the scoring disease severity (score index)} for determining the average disease seveirity index (ADSI)

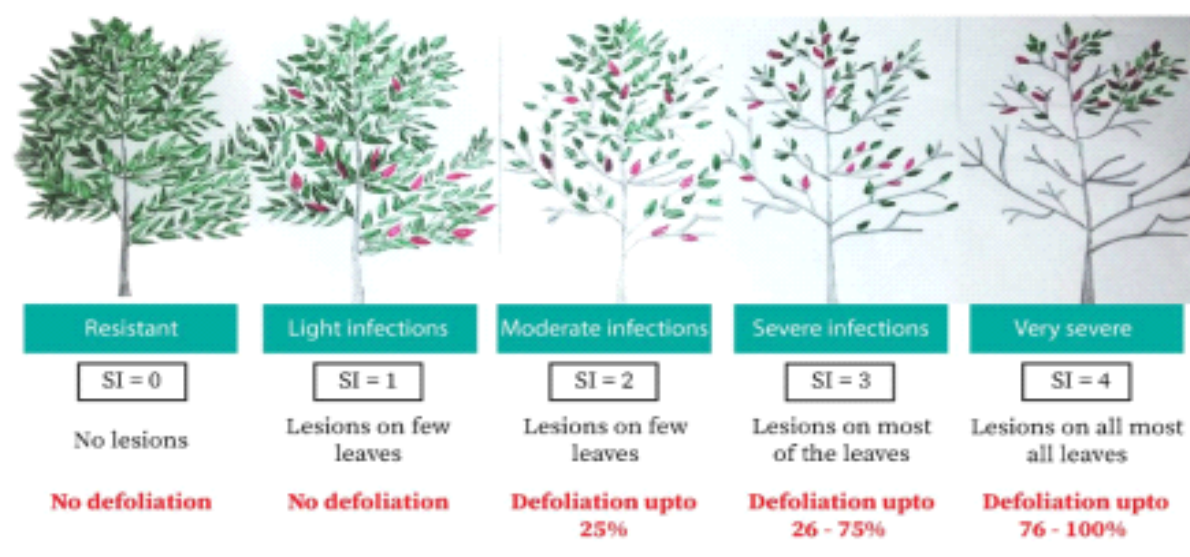

Gambar 1. Indeks penilaian kerapatan tajuk untuk menentukan keparahan serangan penyakit gugur daun pada tanaman karet (Sumber : IRRDB 2019)

Figure 1. Scoring observation on leaffall disease in rubber plants (Source : IRRDB 2019) 


\section{Produksi Tanaman Karet}

Data produksi karet kering dikumpulkan selama bulan Oktober 2019 sampai dengan April 2020. Produksi tanaman karet akan dikorelasikan dengan kerapatan tajuk dengan menggunakan software Minitab 14. Selain itu, akan dianalisis juga pengaruh kerapatan tajuk dalam memengaruhi produksi setiap perlakuan.

\section{Iklim}

Pengamatan iklim yang diamati antara lain kecepatan angin dan curah hujan yang diukur dengan menggunakan alat Automatic Weather Station (AWS) setiap bulan.

\section{HASIL DAN PEMBAHASAN}

\section{Kerapatan Tajuk dan Produksi Tanaman}

Berdasarkan pengamatan di lapangan, gejala penyakit Pestalotiopsis mulai terlihat pada saat daun tua (umur daun > 16 hari). Daun karet yang terinfeksi mengalami perubahan warna dan akhirnya daun gugur. Diduga infeksi Pestalotiopsis terjadi pada saat daun masih muda dengan memanfaatkan luka akibat infeksi penyakit gugur daun lainnya dan berkembang 1-2 bulan dengan membentuk gejala nekrosis bulat pada daun.
Pada wilayah Sumatera bagian Selatan tahun 2018, gugur daun alami terjadi awal bulan Juni dan mulai terbentuk sempurna di Oktober. Serangan awal Pestalotiopsis akan terjadi pada awal Januari di tahun berikutnya dan akan terus gugur hingga gugur daun alami tahun berikutnya. Perkembangan kerapatan tajuk tanaman (\%) pada pohon yang terserang Pestalotiopsis di Kebun Percobaan Pusat Penelitian Karet Sembawa dan kondisi tajuk melalui drone disajikan pada Gambar 2 dan Gambar 3. Gambar 2 memperlihatkan kondisi pada tahun 2019 keparahan PGD Pestalotiopsis lebih tinggi dibandingkan tahun 2020. Pada periode Januari 2019 sampai Maret 2019, kerapatan tajuk semakin menurun dengan cepat hingga Mei 2019. Hal ini sedikit berbeda dengan kondisi Januari -Maret 2020, kerapatan tajuk masih relatif stabil hingga April 2020.

Perlakuan hexakonazol dengan cara fogging mampu mempertahankan tajuk lebih baik dibandingkan perlakuan lainnya. Hal ini terlihat pada bulan April 2019, perlakuan P5 dan P6 berbeda nyata dengan kontrol (Tabel 3). Kerapatan tajuk pada perlakuan P5 dan P6 lebih tinggi berturutturut sebesar 5\% dan 8\% dibandingkan dengan tajuk tanaman kontrol. Tabel 1 juga memperlihatkan pada bulan Mei 2019, perlakuan pemberian pupuk rekomendasi maupun ekstra N (P1 dan P2) mampu

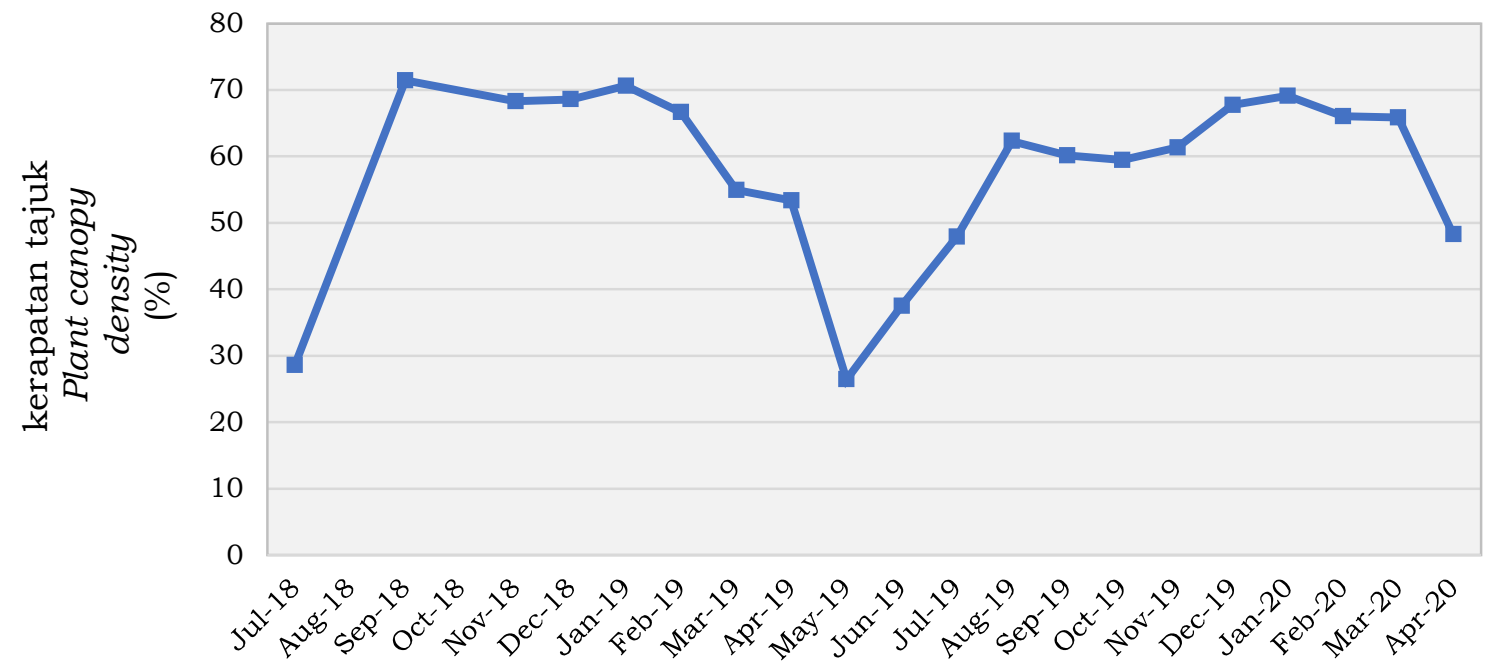

Gambar 2. Kerapatan tajuk pada tanaman karet yang terserang PGD Pestalotiopsis selama Juni 2018 - April 2020 Kebun Percobaan Pusat Penelitian Karet Sembawa.

Figure 2. Canopy density on plants affected by Pestalotiopsis LFD in July 2018 -April 2020 in Research Garden in Rubber Research Institute Sembawa 


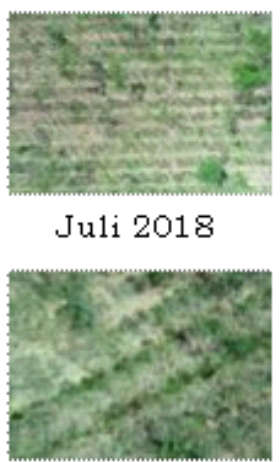

April 2019

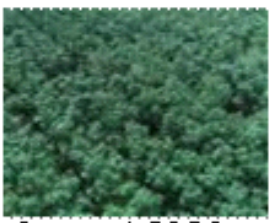

Januari 2020

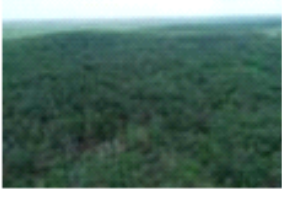

September 2018

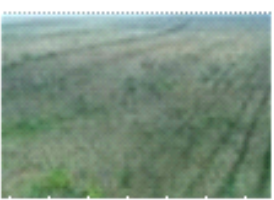

Juni 2019

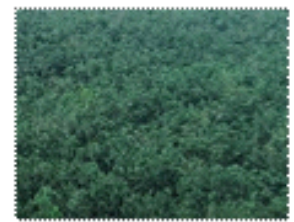

Feb ruari 2020

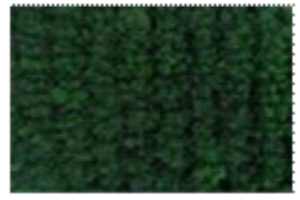

November 2018

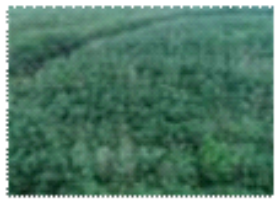

Agustus 2019

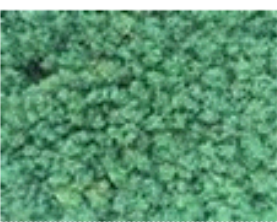

Maret 2020

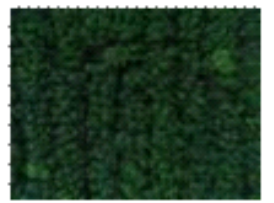

Januari 2019

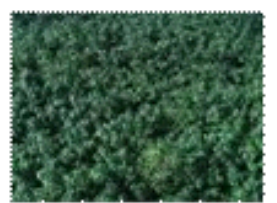

Sep tember 2019

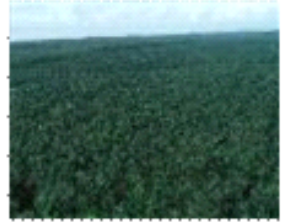

April 2020

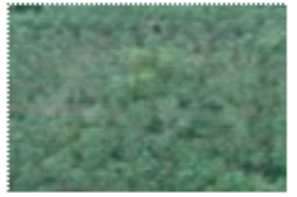

Maret 2019

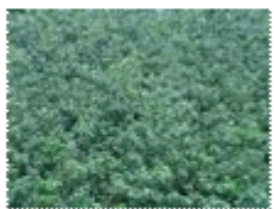

November 2019

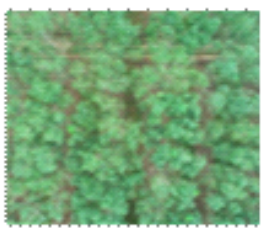

Mei 2020

Gambar 3. Kondisi tajuk tahun 2018-2020

Figure 3. Condition of the canopy in 2018-2020

Tabel 3. Pengaruh beberapa perlakuan terhadap kerapatan tajuk tanaman karet. Table 3. Effect of treatment to canopy density of rubber plants

\begin{tabular}{|c|c|c|c|c|c|c|c|}
\hline \multirow[t]{2}{*}{$\begin{array}{l}\text { Waktu } \\
\text { Period }\end{array}$} & & \multicolumn{6}{|c|}{ Tajuk } \\
\hline & $\mathrm{PO}$ & $\mathrm{P} 1$ & $\mathrm{P} 2$ & P3 & $\mathrm{P} 4$ & P5 & $\mathrm{P} 6$ \\
\hline Jul-18 & $28,067 a$ & $19,71 \mathrm{ab}$ & $15,49 b$ & $21,64 a b$ & $23,68 a b$ & $27,89 a$ & $25,01 \mathrm{ab}$ \\
\hline Sep-18 & $71,54 \mathrm{bc}$ & $75,21 \mathrm{a}$ & $74,87 a b$ & $73,87 a b c$ & $74,06 a b c$ & $72,31 \mathrm{abc}$ & $70,56 c$ \\
\hline Nov-18 & $68,52 d$ & $73,55 a$ & $72,11 \mathrm{abc}$ & $71,24 \mathrm{bc}$ & $72,71 \mathrm{ab}$ & $71,00 \mathrm{bc}$ & $70,62 c$ \\
\hline Dec-18 & $68,00 \mathrm{e}$ & $74,21 \mathrm{a}$ & $73,57 a b$ & $72,94 \mathrm{bc}$ & $73,36 a b c$ & $72,33 c$ & $70,56 \mathrm{~d}$ \\
\hline Jan-19 & $69,39 c$ & $74,80 a$ & $73,43 a b$ & $72,93 a b$ & $73,23 a b$ & $72,54 b$ & $70,57 \mathrm{c}$ \\
\hline Feb-19 & $62,99 b$ & $68,74 a$ & $67,84 a$ & $67,16 a b$ & $67,05 \mathrm{ab}$ & $68,37 a$ & $70,08 a$ \\
\hline Mar-19 & $52,75 d$ & $59,69 a b$ & $61,30 a$ & $60,59 a b$ & $58,73 b$ & $55,68 c$ & $55,58 c$ \\
\hline Apr-19 & $48,23 b$ & $55,13 a b$ & $54,90 a b$ & $55,44 a$ & $54,40 a b$ & $61,40 a$ & $58,42 a$ \\
\hline May-19 & $25,55 \mathrm{e}$ & $42,97 a$ & $38,97 b$ & $35,02 c$ & $35,49 c$ & $32,92 \mathrm{~cd}$ & $31,90 d$ \\
\hline Jun-19 & $38,17 \mathrm{bc}$ & $38,30 \mathrm{bc}$ & $37,36 \mathrm{c}$ & $35,47 d$ & $39,05 b$ & $40,57 a$ & $38,17 \mathrm{bc}$ \\
\hline Jul-19 & $43,77 \mathrm{c}$ & $42,98 c$ & $44,26 c$ & $55,65 b$ & $54,72 b$ & $61,38 a$ & $58,43 a b$ \\
\hline Aug-19 & $57,99 c$ & $63,93 b$ & $67,83 a b$ & $66,92 \mathrm{ab}$ & $67,15 \mathrm{ab}$ & $69,74 a b$ & $71,31 \mathrm{a}$ \\
\hline Sep-19 & $56,60 c$ & $65,75 a b$ & $65,23 a b$ & $64,94 b c$ & $66,17 \mathrm{ab}$ & $68,85 a b$ & $69,78 a$ \\
\hline Oct-19 & $53,25 b$ & $60,60 a b$ & $61,16 a b$ & $64,93 a$ & $64,93 a$ & $65,22 a$ & $68,44 a$ \\
\hline Nov-19 & $58,08 d$ & $66,49 c$ & $68,41 b c$ & $69,58 \mathrm{bc}$ & $71,58 \mathrm{ab}$ & $71,57 \mathrm{ab}$ & $74,99 a$ \\
\hline Dec-19 & $67,05 e$ & $69,63 d$ & $71,706 \mathrm{c}$ & $71,46 c$ & $72,85 b$ & $73,44 a b$ & $74,16 a$ \\
\hline Jan-20 & $63,10 \mathrm{e}$ & $69,88 \mathrm{~cd}$ & $69,36 d$ & $70,49 \mathrm{bc}$ & $71,08 b$ & $71,55 b$ & $72,66 a$ \\
\hline Feb-20 & $61,24 d$ & $65,95 c$ & $65,87 \mathrm{c}$ & $66,11 c$ & $67,49 b$ & $67,79 b$ & $69,15 a$ \\
\hline Mar-20 & $65,81 \mathrm{e}$ & $67,09 d$ & $68,90 c$ & $69,43 \mathrm{bc}$ & $69,87 \mathrm{bc}$ & $70,44 b$ & $71,66 a$ \\
\hline Apr-20 & $48,86 \mathrm{e}$ & $52,22 d$ & $52,85 d$ & $54,28 \mathrm{~cd}$ & $56,65 \mathrm{bc}$ & $58,66 b$ & $61,24 a$ \\
\hline
\end{tabular}

Keterangan: Nilai yang diikuti oleh huruf yang berbeda pada baris yang sama berbeda nyata pada uji jarak berganda DMRT pada taraf 5\% (PO = kontrol, P1=pupuk 100\% dosis rekomendasi, $\mathrm{P} 2=$ ekstra $25 \% \mathrm{~N}, \mathrm{P} 3=$ ekstra $25 \% \mathrm{~K}, \mathrm{P} 4=$ fungisa pada 
memulihkan kerapatan tajuk lebih cepat dibandingkan tanpa pemupukan ekstra N. Pada bulan yang sama juga, kombinasi perlakuan pemberian fogging dan pupuk ekstra 25\% $\mathrm{N}$ mampu mempertahankan kerapatan tajuk dibandingkan perlakuan lainnya. Hal tersebut mengindikasikan bahwa pupuk $\mathrm{N}$ mampu memulihkan kondisi tajuk lebih cepat dibandingkan kontrol dan perlakuan lainnya.

Pada Gambar 3 terlihat tahun 2020, keparahan PGDP lebih rendah di tahun 2019, yang ini disebabkan oleh pengaruh El Nino tahun 2019 dengan kondisi bulan kering yang lama dan kelembaban yang rendah. Kondisi tersebut mengakibatkan kejadian penyakit tertunda hingga 2-3 bulan sehingga puncak produksi bisa tercapai sampai gugur daun alami. Data curah hujan dan kelembapan tahun 2018, 2019 dan 2020 disajikan pada Gambar 4.

Berdasarkan hasil analisis korelasi, kerapatan tajuk dengan produksi tanaman karet menunjukkan korelasi positif dengan nilai pearson correlation sebesar 0,65. Artinya semakin tinggi kerapatan tajuk maka produksi tanaman karet juga meningkat. Kerapatan tajuk memengaruhi $65 \%$ dari produksi lateks, sementara sisanya adalah faktor lainnya. Berikut akan dijelaskan pengaruh masing-masing perlakuan terhadap kondisi tajuk dan juga produksi.

\section{Aplikasi Pupuk 100\% Dosis Rekomendasi}

Berdasarkan Gambar 5 terlihat aplikasi pupuk 100\% dosis rekomendasi memberikan peningkatan kerapatan tajuk $4 \%$ dan kenaikan produksi $3 \mathrm{~g}$ $\mathrm{kk} /$ pohon/sadap dibandingkan kontrol (Gambar 5). Meskipun kenaikan kerapatan tajuk dan produksi tidak terlalu tinggi namun masih bisa menjadi bahan pertimbangan untuk aplikasi pupuk dalam pengendalian penyakit daun. Pengaruh pupuk juga mempercepat pembentukan
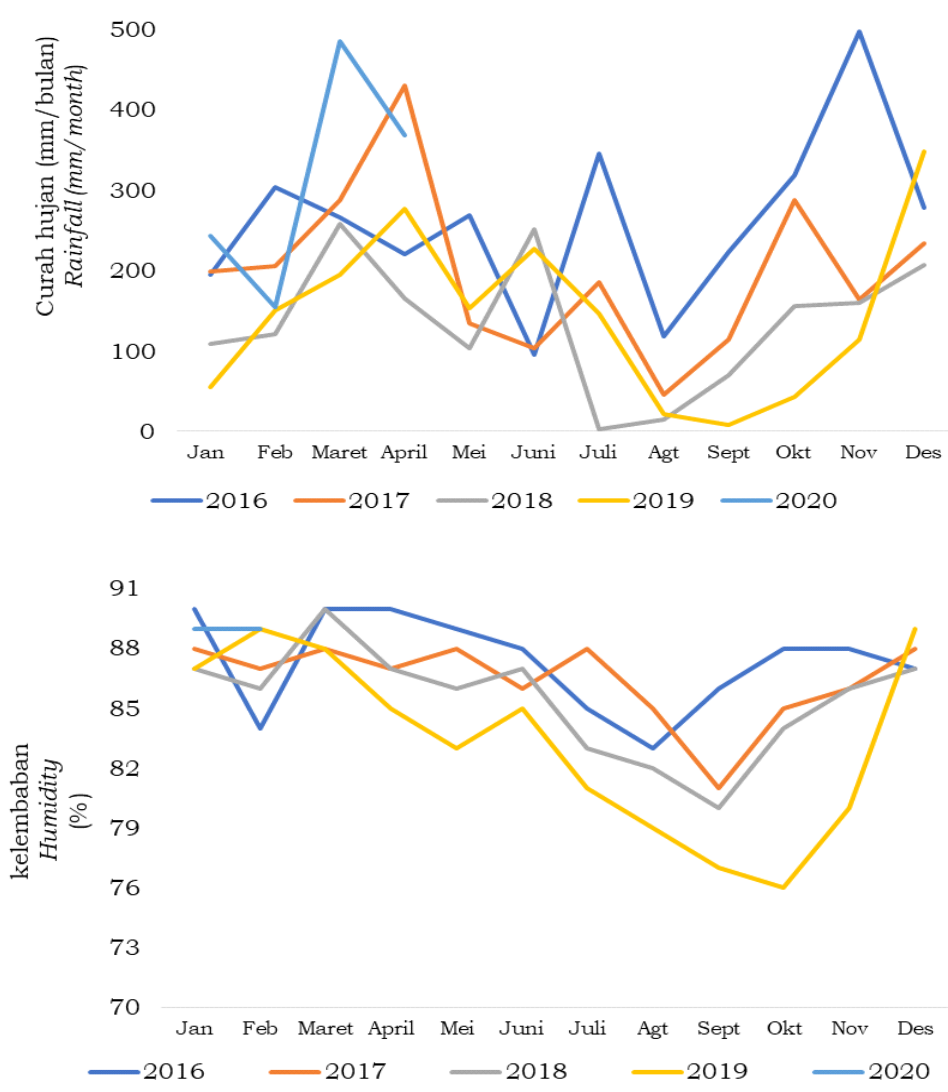

Gambar 4. Data Curah hujan dan kelembaban

Figure 4. Rainfall and Humidity data 

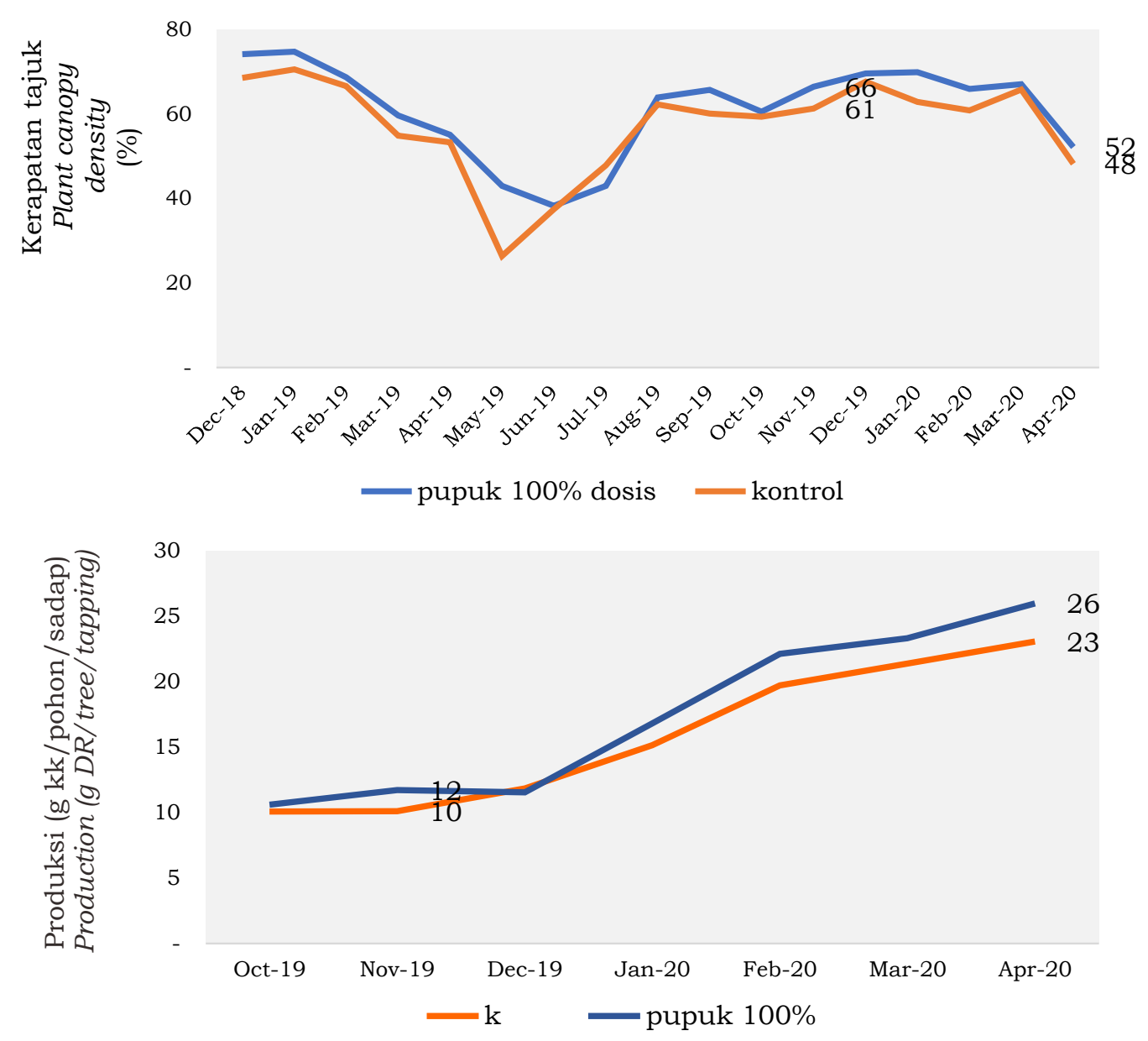

Gambar 5. Pengaruh aplikasi pupuk 100\% dosis rekomendasi terhadap kondisi kerapatan tajuk dan produksi pada tanaman terserang PGDP

Figure 5. The effect of $100 \%$ fertilizer dosage recommendation applications to the canopy density and yield on plant affected by Pestalotiopsis leaffall disease

daun baru setelah gugur daun alami. Wijaya et al. (2014) melaporkan bahwa penundaan pemupukan akan berpengaruh terhadap produksi karet pada tahun berikutnya.

Unsur nutrisi yang diaplikasikan pada penelitian ini adalan unsur N, P, K dan Mg. Nitrogen adalah komponen penting dalam penyusunan struktur klorofil, protoplasma, bagian utama protein, dan asam-asam nukleat. Peran unsur ini esensial dalam mendukung pertumbuhan dan perkembangan di berbagai jaringan tanaman (Brady \& Weil, 2002; Fahmi et al. 2010).

Unsur hara $\mathrm{N}$ (Nitrogen) sebagai komponen enzim berperan penting dalam menstimulasi pertumbuhan, meningkatkan fotosintesis dan asam amino. Kekurangan unsur ini akan mengakibatkan gangguan pertumbuhan dan produksinya (Tisdale \& Nelson, 1975). Budiman (1997) melaporkan bahwa nitrogen erat hubungannya dengan sistem pertahanan tanaman terhadap serangan penyakit. Unsur hara lain seperti $\mathrm{P}$ (fosfor) juga sangat penting bagi tanaman seperti untuk merangsang pertumbuhan akar dan pertumbuhan tanaman karet (Saufe et al. 2018). Unsur ini merupakan bahan mentah pembentuk sejumlah struktur protein tertentu dan membantu fotosintesis serta respirasi (Lingga, 1989). Kekurangan fosfor pada tanaman karet muda berdampak pada pengurangan jumlah daun dan menjadikan pertumbuhan tanaman terhambat. Pengaruh pemberian fosfor pada tanaman karet klonal dapat meningkatkan pertumbuhan sampai 10\% dibandingkan yang tidak diberikan fosfor 
(Tajuddin, 1981). Lim (1974) menyatakan bahwa pemberian pupuk ekstra Nitrogen segera setelah gugur daun alami dapat mencegah serangan Oidium heveae. Pemberian ekstra Nitrogen akan mendorong tanaman lebih cepat membentuk daun muda sebelum munculnya $O$. heveae. Seperti telah diketahui bahwa daun muda lebih sensitif terhadap serangan patogen.

Unsur hara K (Kalium) berpengaruh terhadap jumlah stomata pada daun normal, mekanisme gerak membuka menutup stomata (Wilmer, 1983), dan luas daun normal (Steineck \& Haeder, 1978). Ketiga hal tersebut merupakan bagian dari sistem ketahanan mekanik dari jaringan daun terhadap serangan penyakit. Pada kondisi tanaman yang mengalami kekurangan $\mathrm{K}$ menyebabkan komponen ketahanan mekanik tersebut terganggu, sehingga akan memudahkan penetrasi patogen pada daun Magnesium (Mg) berperan dalam pembentukan klorofil (Lingga, 1989). Kekurangan Magnesium dapat mengurangi kemampuan tanaman berfotosintesis sehingga dukungan terhadap pertumbuhan menurun. Magnesium dibutuhkan dalam beberapa sistem enzim sebagai aktivator termasuk metabolisme fosfat (Tajuddin, 1981).

\section{Aplikasi Pupuk Ekstra 25\% Unsur N}

Aplikasi pupuk ekstra 25\% N memberikan peningkatan kerapatan tajuk $5 \%$ dan kenaikan produksi 5 gr g/p/s dibandingkan kontrol berarti setiap 1\% kerapatan tajuk maka produksi naik $1 \mathrm{~g} / \mathrm{p} / \mathrm{s}$ lebih tinggi dari pemakaian pupuk 100\% dosis rekomendasi. Berdasarkan penelitian yang dilakukan Budiman (1997)
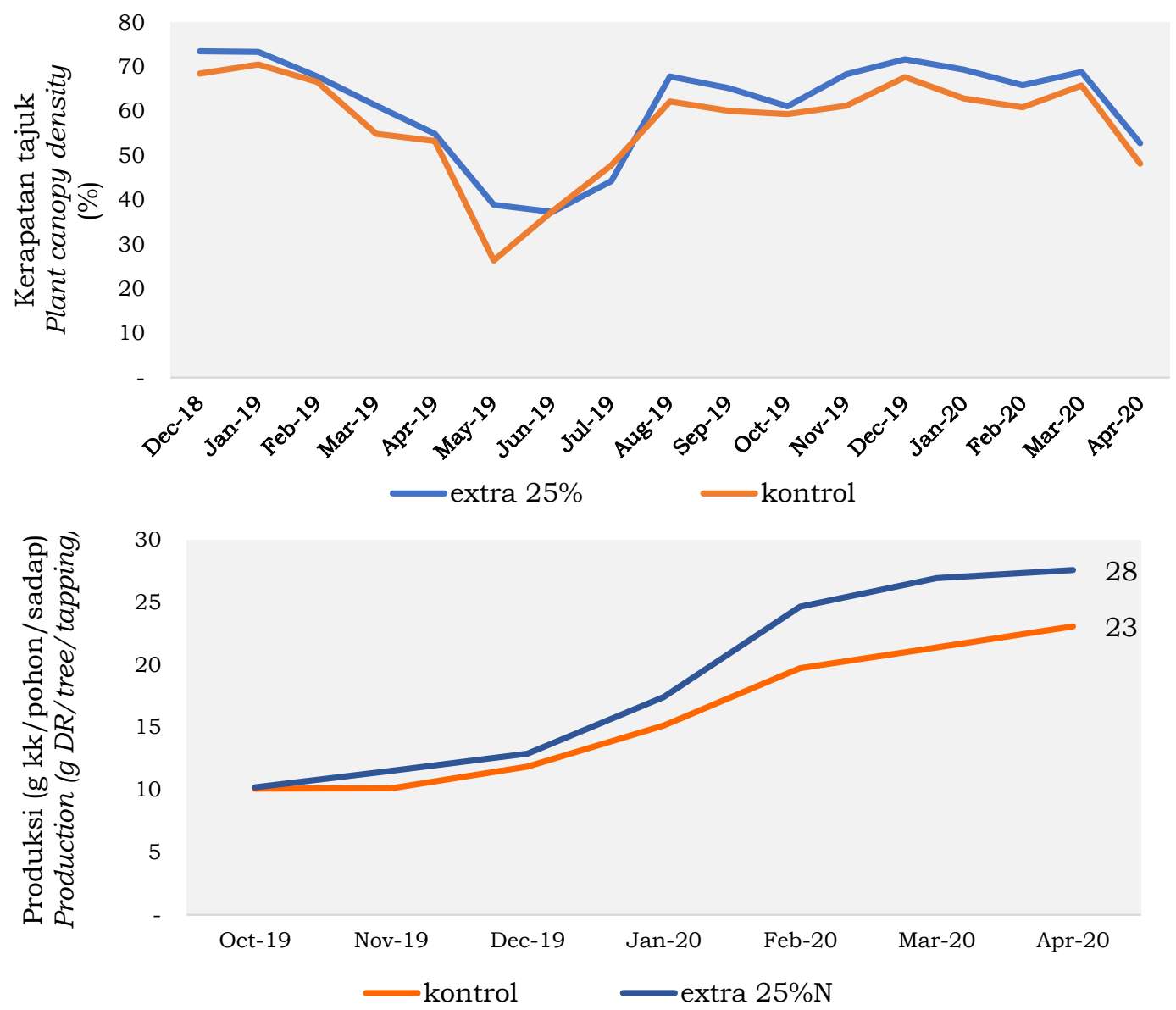

Gambar 6. Pengaruh aplikasi pupuk ekstra 25\% N terhadap kondisi tajuk dan produksi pada tanaman terserang PGDP

Figure 6. The effect of extra $25 \% N$ fertilizer applications to the canopy density and yield on plant affected by Pestalotiopsis leaffall disease 
menyatakan bahwa urea tidak menekan intensitas infeksi penyakit, namun membantu mempertahankan pertumbuhan tanaman terutama dalam pembentukan daun, sehingga serangan penyakit daun tersebut tidak menyebabkan daun gugur.

Beberapa penelitian melaporkan pengendalian penyakit gugur daun seperti Corynespora cassiicola. Dalam kasus ini selain penggunaan klon resisten dan aplikasi fungisida, terbukti bahwa perbaikan kultur teknis cukup efektif mengendalikan penyakit tersebut. Kultur teknis yang dimaksud meliputi pengendalian gulma teratur, dosis pemupukan, komposisi dan waktu aplikasi yang tepat, serta pemanen lateks sesuai potensi tanaman (Suwarto et al. 1986; Rajalakshmy \& Kothandaraman, 1996). Penelitian di Malaysia menyatakan bahwa penambahan pupuk Nitrogen untuk mengurangi serangan Oidium heveae di mana waktu pemunculan daun baru dipercepat sehingga mengurangi periode kerentanan daun muda. Dalam pengendalian $O$. heveae, pemupukan nitrogen dengan dua kali dosis yang dianjurkan akan mempercepat proses dan memperbanyak pembentukan daun-daun baru (Anonim., 1983). Sebagai sumber N, Hashim et al (1996) menganjurkan pemberian $100 \mathrm{~g} /$ pohon $\mathrm{ZA}$ sebagai tambahan dosis anjuran yang diberikan sebulan sebelum tumbuhnya daun baru.

Pawirosoemardjo (1984) menyatakan bahwa unsur $\mathrm{N}$ merupakan unsur pembentuk senyawa fitoaleksin. Pada daun karet yang terserang C. gloeosporioides, fitoaleksin yang terbentuk dapat bersifat toksik bagi patogen atau berperan sebagai senyawa fenolat yang dapat membatasi kerusakan akibat serangan patogen, melalui suatu proses yang disebut reaksi hipersensivitas. Pemberian pupuk melalui daun diyakini dapat memperbaiki proses fisiologi jaringan daun sehingga fitoaleksin yang terbentuk dapat memperbaiki katahanan jaringan daun terhadap serangan penyakit gugur daun Colletotrichum.

\section{Aplikasi Ekstra 25\% Unsur K}

Pemberian pupuk ekstra Kalium pada tanaman karet terbukti meningkatkan ketahanan tanaman baik terhadap cekaman suhu rendah maupun kekeringan, dan juga menekan tingkat gangguan penyakit gugur daun Corynespora. Berdasarkan survei pada beberapa perkebunan karet di Lampung dan Sumatera Selatan menunjukkan bahwa tanaman dengan status $\mathrm{K}$ yang tinggi memiliki toleransi yang lebih baik terhadap serangan penyakit daun Corynespora (Thomas et al., 2003). Kerapatan tajuk meningkat dengan aplikasi pupuk ekstra 25\% K memberikan kerapatan tajuk $6 \%$ dan kenaikan produksi $6 \mathrm{~g} / \mathrm{p} / \mathrm{s}$ dibandingkan kontrol (Gambar 7).

Kebun-kebun yang terdapat pada lahan klas kurang subur atau tidak melakukan pemupukan dalam jangka lama menyebabkan kondisi tanaman menjadi lemah sehingga intensitas serangan lebih tinggi (Rajalakshmy et al, 1979). Oleh karena itu pemberian pupuk ekstra $(30 \%)$ menjadi sangat penting untuk menjaga pertumbuhan tanaman lebih baik sehingga lebih tahan terhadap serangan C. cassiicola (Situmorang \& Budiman, 1985; Situmorang, 1995). Kombinasi pupuk Nitrogen dengan benomil diaplikasikan pada awal musim gugur daun alami dapat mengurangi kerusakan oleh penyakit gugur daun (Hashim etal., 1996).

Beberapa penelitian menunjukkan bahwa stres suhu udara dan stres air pada tanaman karet dapat dikurangi dengan peningkatan pemupukan K. Ditemukan asosiasi antara tingkat serangan penyakit daun Corynespora dengan status hara $\mathrm{K}$ di daun di Lampung dan Sumatera Selatan. Tanaman yang memiliki status hara $\mathrm{K}$ yang tinggi memiliki ketahanan yang lebih baik terhadap penyakit tersebut. Mekanisme ketahanan terhadap penyakit daun dengan status hara Kalium ini perlu dikaji lebih lanjut (Thomas, et al. 2003).

Ekstra pupuk $1.5 \mathrm{x}$ dosis anjuran mempercepat pemulihan tunas atau pemulihan tajuk tanaman sehingga dapat selamat dari serangan C. gloeosporioides. (Pawirosoemardjo, 1995). Hal ini diperkuat oleh Situmorang dan Sihombing (1995) bahwa keparahan penyakit gugur daun Colletotrichum di entres karet klon PR 300 lebih rendah pada perlakuan pupuk satu kali dosis dan dua kali dosis anjuran dibandingkan dengan tanpa pemberian pupuk, di mana tebal kutikula daun lebih tinggi pada perlakuan yang diberikan pupuk dua kali dosis. 

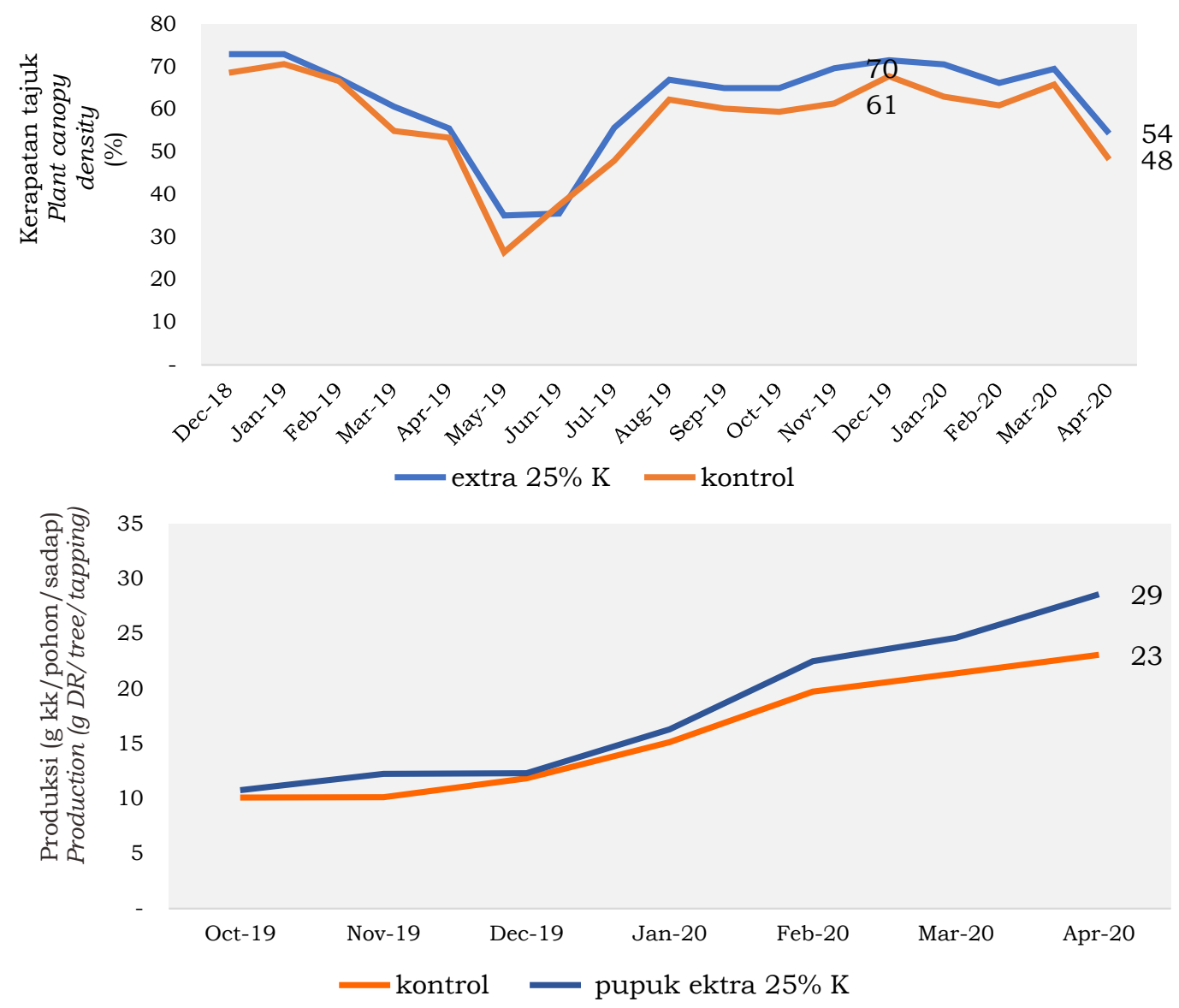

Gambar 7. Pengaruh aplikasi pupuk ekstra 25\% K terhadap kondisi tajuk dan produksi pada tanaman terserang PGDP

Figure 7. The effect of extra $25 \% \mathrm{~K}$ fertilizer applications to the canopy density and yield on plant affected by Pestalotiopsis leaffall disease

\section{Aplikasi Fungisida Pada Gawangan}

Penggunaan fungisida untuk penyemprotan gawangan adalah mengurangi densitas spora di areal perkebunan karet. Pestalotiopsis yang bersifat opportunistic dan masih bisa bertahan hidup di serasah daun dan mudah terbawa angin menenpel ke daun yang sedang terbentuk. Kepekatan spora dalam percobaan terlihat menurun yang dibuktikan adanya meningkatnya tajuk di areal yang disemprot gawangannya. Gambar 8 memperlihatkan peningkatan kerapatan tajuk 9\% dan kenaikan produksi $5 \mathrm{~g} / \mathrm{p} / \mathrm{s}$ dibandingkan kontrol pada perlakuan ini. Fungisida yang digunakan untuk aplikasi gawangan yaitu Thiopanat metil dengan dosis $2 \mathrm{cc} /$ liter, dibutuhkan sekitar 500 liter suspensi larutan, alat yang digunakan untuk aplikasi ini yaitu knapsack sprayer.
Penyemprotan gawangan akan lebih efektif jika di sekitar gawangan bersih dari gulma.

Kombinasi fungisida (Benomil, Metiltiofanat, dan Mankozeb) dengan pupuk urea $0.2 \%$ dilaporkan efektif menekan intensitas serangan C. gloeosporioides, sekaligus memperbaiki performa tanaman karet (Budiman dan Ben, 2001). Situmorang (1989) juga melaporkan bahwa pupuk urea 6 $\mathrm{g} / 1$ atau fungisida mankozeb efektif menekan perkembangan penyakit gugur daun Colletotrichum. Tetapi efektivitas pupuk ekstra urea dalam menekan penyakit ini masih di bawah fungisida Mankozeb. Dalam pengendalian penyakit gugur daun Colletotrichum di pembibitan karet, fungisida Mankozeb dapat dicampurkan dengan pupuk Urea pada saat penyemprotan untuk menghemat tenaga, waktu dan biaya aplikasi. Tetapi apabila fungisida Mankozeb 

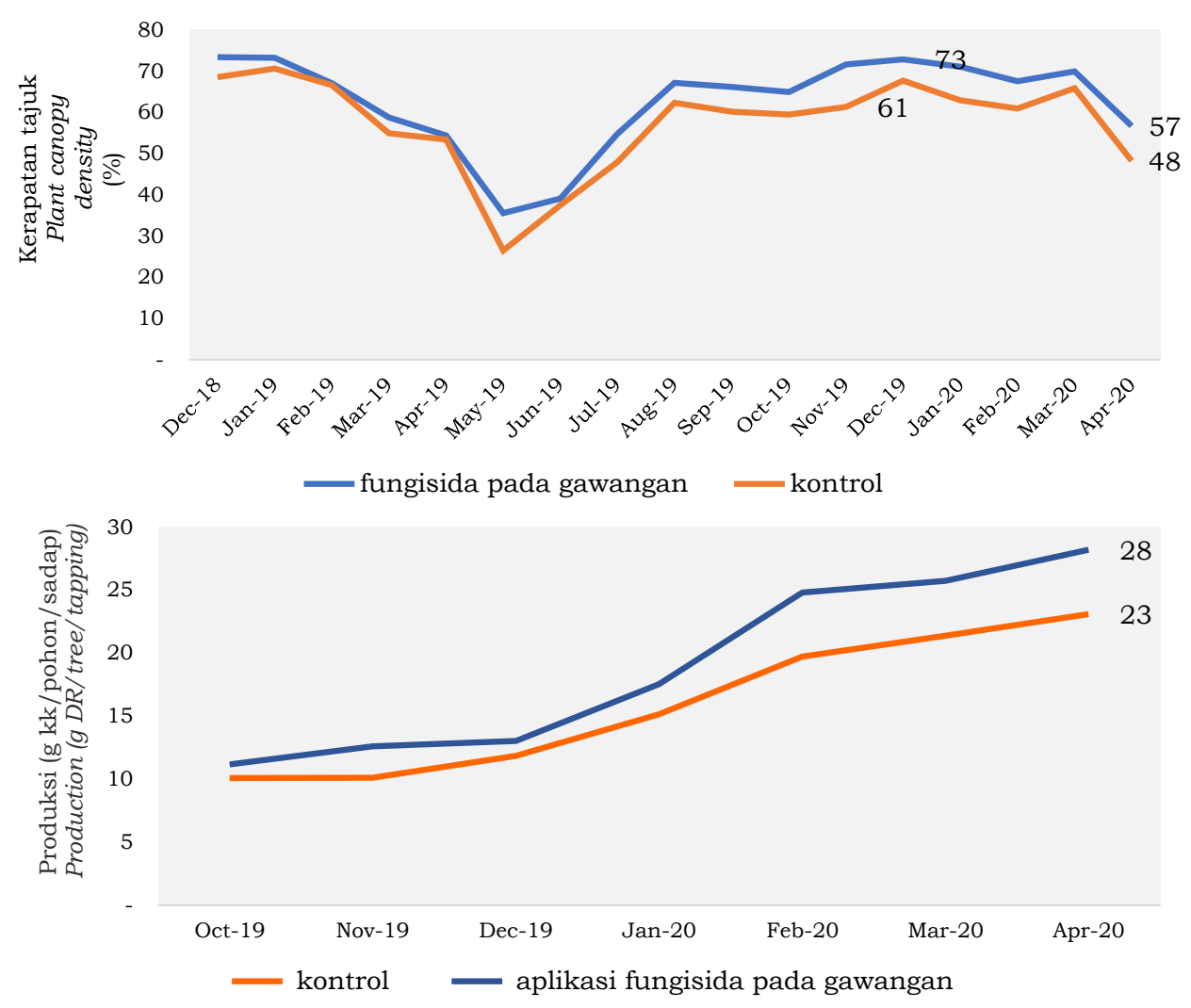

Gambar 8. Pengaruh aplikasi fungisida pada gawangan terhadap kondisi tajuk dan produksi pada tanaman terserang PGDP

Figure 8. The effect of blanket fungicide applications on ground cover to the canopy density and yield on plant affected by Pestalotiopsis leaffall disease

tidak tersedia pupuk Urea dapat digunakan secara tersendiri untuk mengurangi serangan patogen. Fungisida dapat diaplikasikan pada bibit tanaman karet dalam polibag yang terserang C. cassiicola. Pemberantasan dengan fungisida pada kebun produksi yang mengalami serangan C. cassiicola dapat dianjurkan sepanjang secara ekonomis masih memberikan hasil yang menguntungkan. Fungisida yang dianjurkan adalah Dithane M 45, Bavistin dan Benlate 50WP (Pawirosoemardjo, 2004).

\section{Aplikasi Fungisida dengan Cara Fogging}

Perlindungan tanaman terhadap serangan patogen efektif apabila fungisida diaplikasikan pada saat flush baru mekar dan juga diulang sedikitnya 2 kali dengan interval paling lama 10 hari. Gambar 9 menunjukan aplikasi fungisida dengan cara fogging cukup efektif meningkatkan kerapatan tajuk 9\% dibandingkan kontrol, sedangkan kenaikan produksi sebesar 8 $\mathrm{g} / \mathrm{p} / \mathrm{s}$.

Pengendalian penyakit gugur daun $O$. heveae dengan cara fogging banyak dilakukan di pembibitan maupun di lapangan. Belerang cirrus dihembuskan menggunakan alat penghembus berupa hand duster dan di areal tanaman produksi perlu digunakan alat penghembus yang mempunyai kekuatan 6 tenaga kuda. Sementara untuk di pembibitan, alat pengabutan berupa mesin fogger dan Full Fog K 20. Selain belerang, fungisida berbahan aktif Triadimefon dalam suspensi air yang disemprotkan dengan alat semprot punggung dengan dosis fungisida 600 liter/ha (Pawirosoemardjo, 2004). 

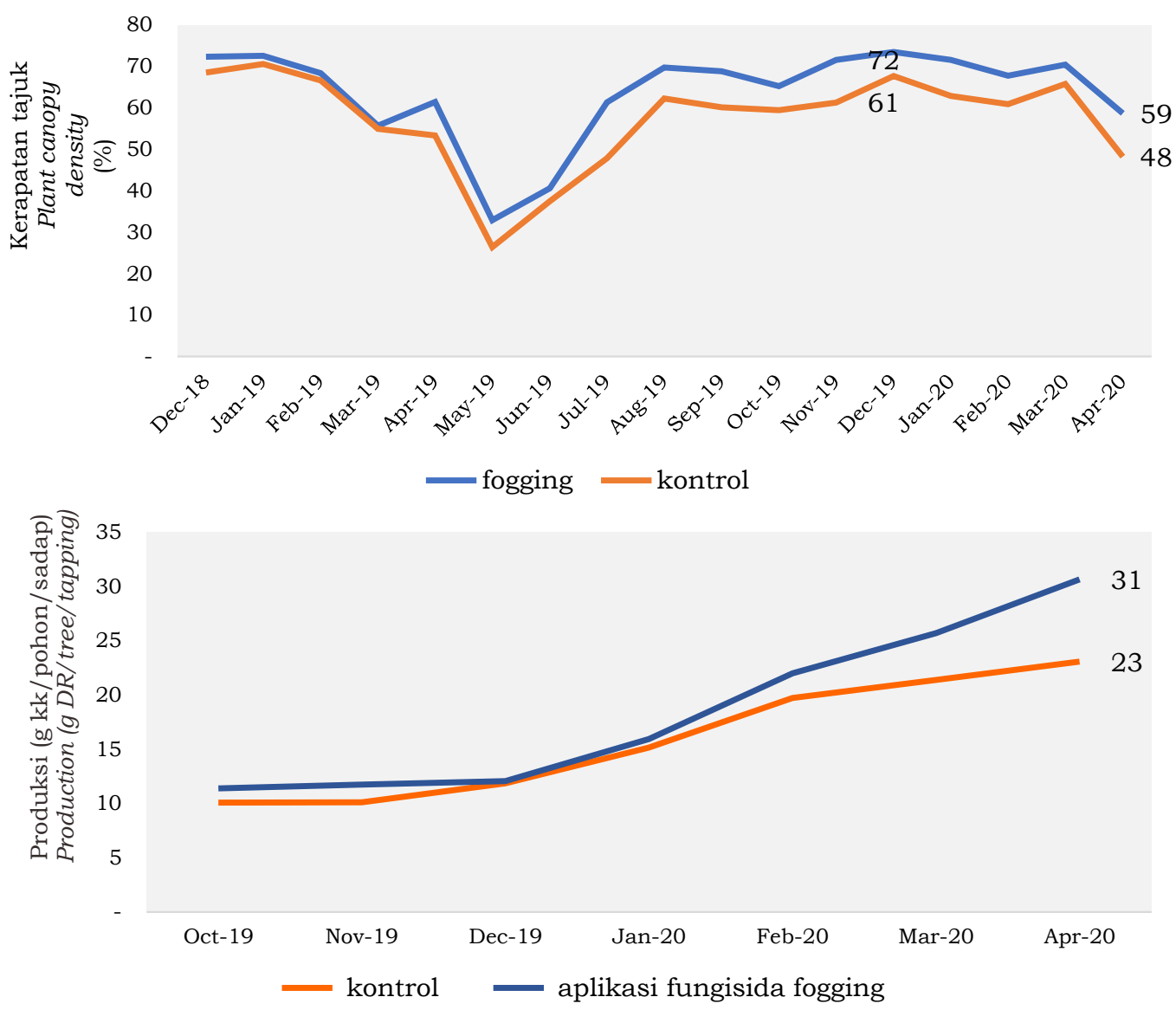

Gambar 9. Pengaruh aplikasi fungisida dengan cara fogging terhadap kerapatan tajuk dan produksi karet pada tanaman terserang PGDP

Figure 9. The effect of fungicide applications by fogging to the canopy density and rubber yield on plant affected by Pestalotiopsis leaffall disease

\section{Aplikasi Pupuk Ekstra $25 \%$ N,K dan Fungisida pada Gawangan dan Fogging}

Pemupukan ektra 25\% N, K dikombinasi dengan aplikasi fungisida baik di gawangan maupun fogging memacu peningkatan kerapatan tajuk hingga 9\%. Peningkatan kerapatan tajuk diikuti dengan meningkatkan produksi karet sebesar 10 $\mathrm{g} / \mathrm{p} / \mathrm{s}$ di atas kontrol. Performa tanaman yang optimal akan diperoleh kondisi baik apabila pemeliharaannya mengikuti standar yang telah ditetapkan. Namun demikian prinsip penerapan pengendalian penyakit tetap harus mempertimbangkan aspek ekonomis. Jika peningkatan kerapatan tajuk pada kombinasi perlakuan ini hampir sama dengan perlakuan tunggal, maka perlakuan yang paling ekonomis menjadi pilihan.
Pemupukan menjadi kunci dalam pengendalian penyakit Pestalotiopsis ini. Kecukupan unsur hara di dalam tanaman akan memberikan dukungan dalam pembentukan tajuk baru yang lebih baik dan cepat setelah gugur daun alami. Pertumbuhan tajuk yang lebih cepat tersebut menyebabkan meningkatkan kemampuan menahan serangan penyakit daun, karena daun telah melampaui stadium yang lewat kritis. Meskipun daun tersebut masih dapat terserang, namun daun tersebut tidak mengalami gugur. Aplikasi fungisida secara berulang 4-5 kali akan melindungi daun hingga mencapai puncak produksi sekitar April-Mei. Selain pemupukan dan aplikasi fungisida tersebut, sistem sadap tanaman produksi harus mengacu pada potensi aktual setiap klon karet yang memiliki batas kemampuan tertentu terhadap sistem sadap. 

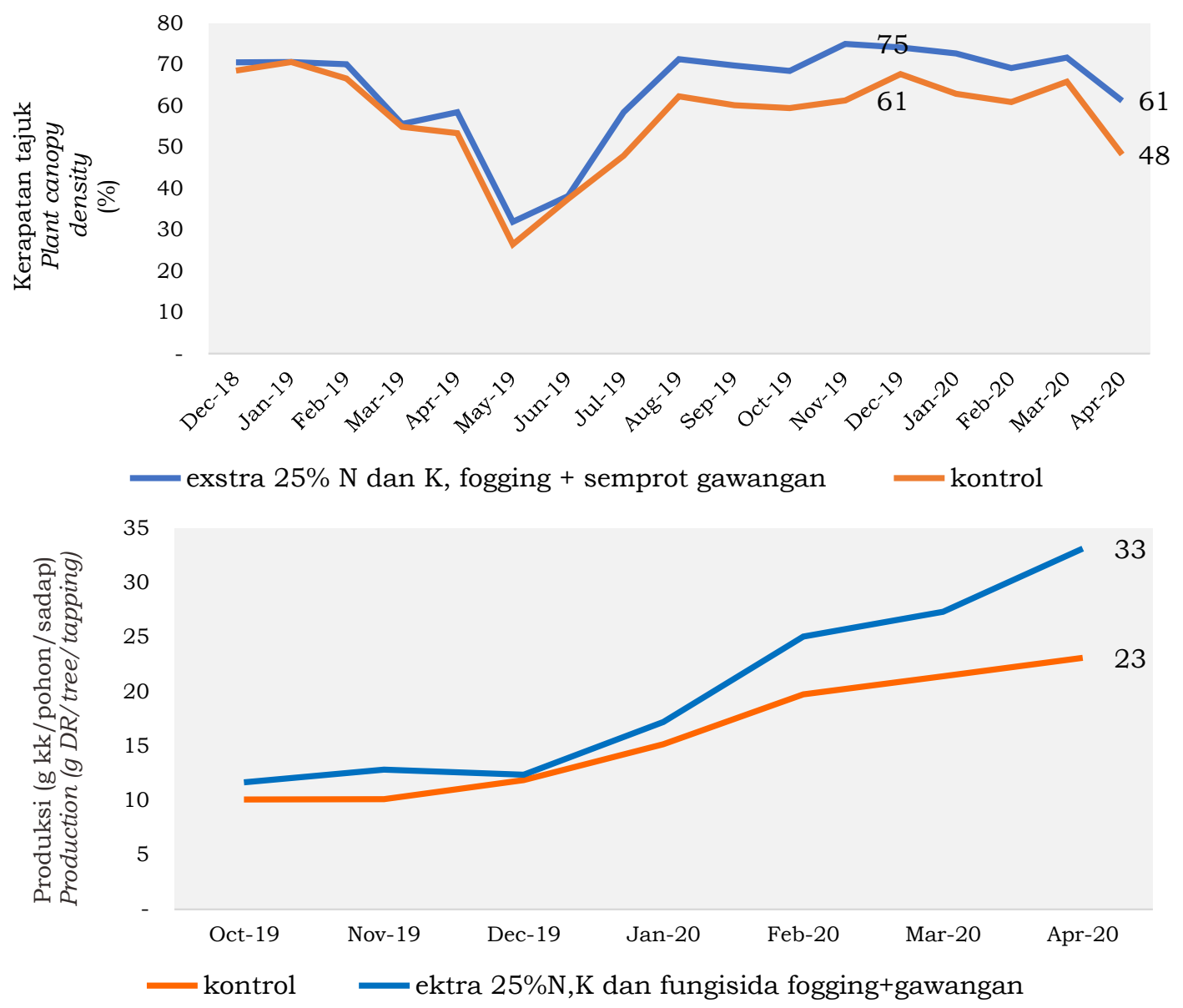

Gambar 10. Pengaruh aplikasi pupuk ekstra 25\% N, K dan fungisida pada gawangan dan fogging terhadap kondisi tajuk dan produksi pada tanaman terserang PGDP

Figure 10. The effect of extra 25\% N, K fertilizer and fungicide on ground cover and fogging applications to the canopy density and yield on plant affected by Pestalotiopsis leaf fall disease

Jenis fungisida untuk penyemprotan gawangan dan fogging yaitu fungisida sistemik, yang telah di uji secara in vitro mampu menghambat miselium Pestalotiopsis ini. Pengendalian penyakit yang disebabkan oleh cendawan umumnya menggunakan fungisida kimia karena dapat mengendalikan penyakit secara cepat, pengaruhnya langsung dapat dilihat serta lebih praktis (Bailey \& Jeger, 1992; Untung, 2001). Berdasarkan mekanisme kerjanya pada tanaman, terdapat dua jenis fungisida yaitu fungisida kontak dan fungisida sistemik. Fungisida kontak bekerja di permukaan tanaman dan mematikan atau menghambat patogen yang bersentuhan langsung dengan bahan aktifnya. Bahan aktif fungisida kontak meracuni bagian tubuh cendawan yang beragam sehingga tidak menimbulkan ketahanan. Berbeda dengan fungisida kontak, bahan aktif fungisida sistemik diserap oleh jaringan tanaman, dan didistribusikan ke seluruh bagian jaringan tanaman. Bahan aktif fungisida tersebut menghambat perkembangan patogen yang telah menginfeksi jaringan tanaman. Fungisida sistemik mempunyai sasaran bunuh yang spesifik sehingga beresiko munculnya resistensi baru dari patogen (Georgopoulos, 1982) dan terbentuknya ras baru.

Penuruanan intensitas serangan Pestalotiopsis juga terkait dengan pemberian unsur hara ekstra. Selain tanaman karet membutuhkan unsur hara untuk pertumbuhan dan produktivitasnya, ketersedian nutrisi yang cukup juga berperan dalam menjaga sistem ketahanan tanaman terhadap cekaman lingkungannya. 
Pemupukan berperan dalam perlindungan tanaman karet secara tidak langsung yaitu menekan perkembangan patogen, melalui induksi kesehatan tanaman karet. Beberapa penelitian membahas mengenai peran nitrogen dan kalium telah dilakukan dalam usaha perlindungan tanaman melalui pemupukan (Veresoglou et al. 2013; Wang et al. 2013; Gao et al. 2018).

\section{Jumlah Daun Gugur}

Jumlah daun gugur yang jatuh pada jaring penampung (Gambar 11) dari bulan Februari-Juni 2020 terlihat bulan Mei paling banyak jumlah daun gugur, hal ini disebabkan karena serangan Pestalotiopsis terjadi sangat cepat dengan keparahan tinggi yang terjadi pada tanggal 18-19 April 2020, hanya waktu 2 hari, hampir semua daun muncul gejala nekrosis dan menguning. Data jumlah daun gugur disajikan pada Gambar 12. Selanjutnya bulan Februari 2020 juga lebih banyak daun gugur dibanding bulan Maret dan April, hal ini disebabkan gejala baru muncul pada bulan Februari 2020 dan kecepatan angin juga tinggi dibandingkan bulan Maret-Mei 2020 (Gambar 13). Kunci pengendalian Pestalotiopsis adalah mempertahankan tajuk di April Mei yang merupakan puncak metabolisme tanaman karet.

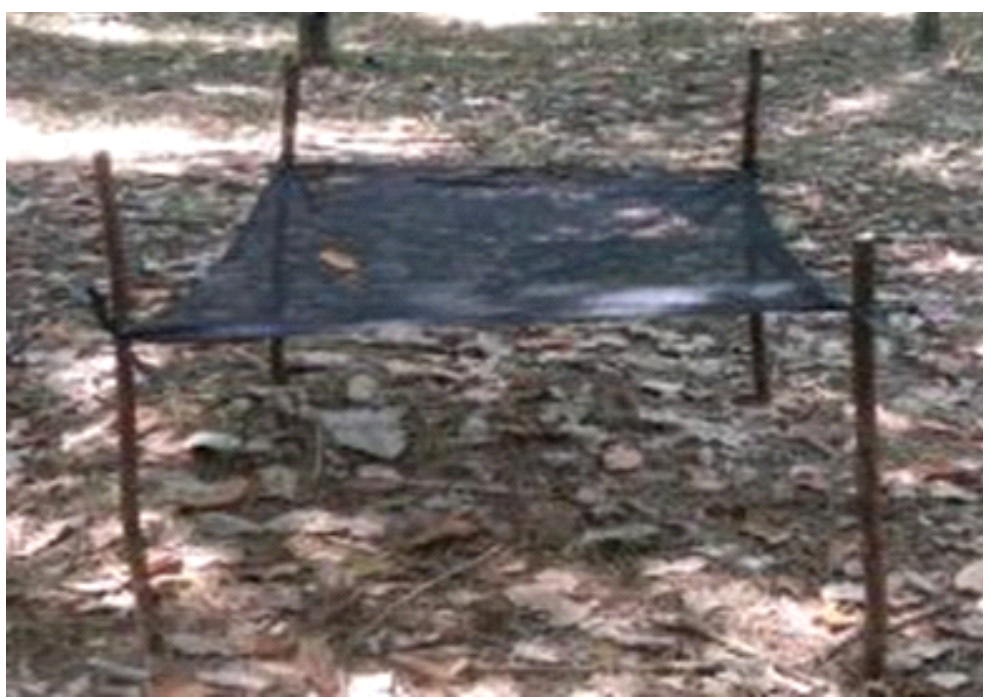

Gambar 11. Jaring penampung daun yang gugur Figure 11. Fallen leaf container net

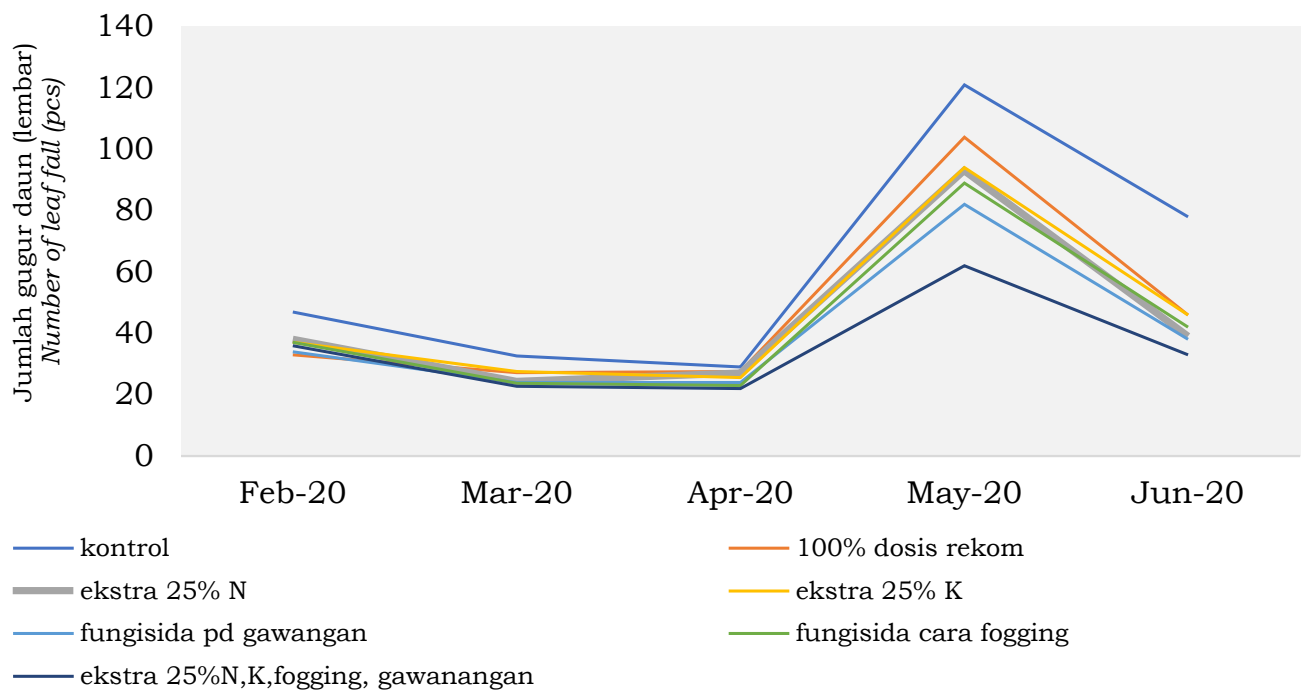

Gambar 12. Jumlah daun gugur pada masing-masing perlakuan Figure 12. Number offallen leafin each treatment 


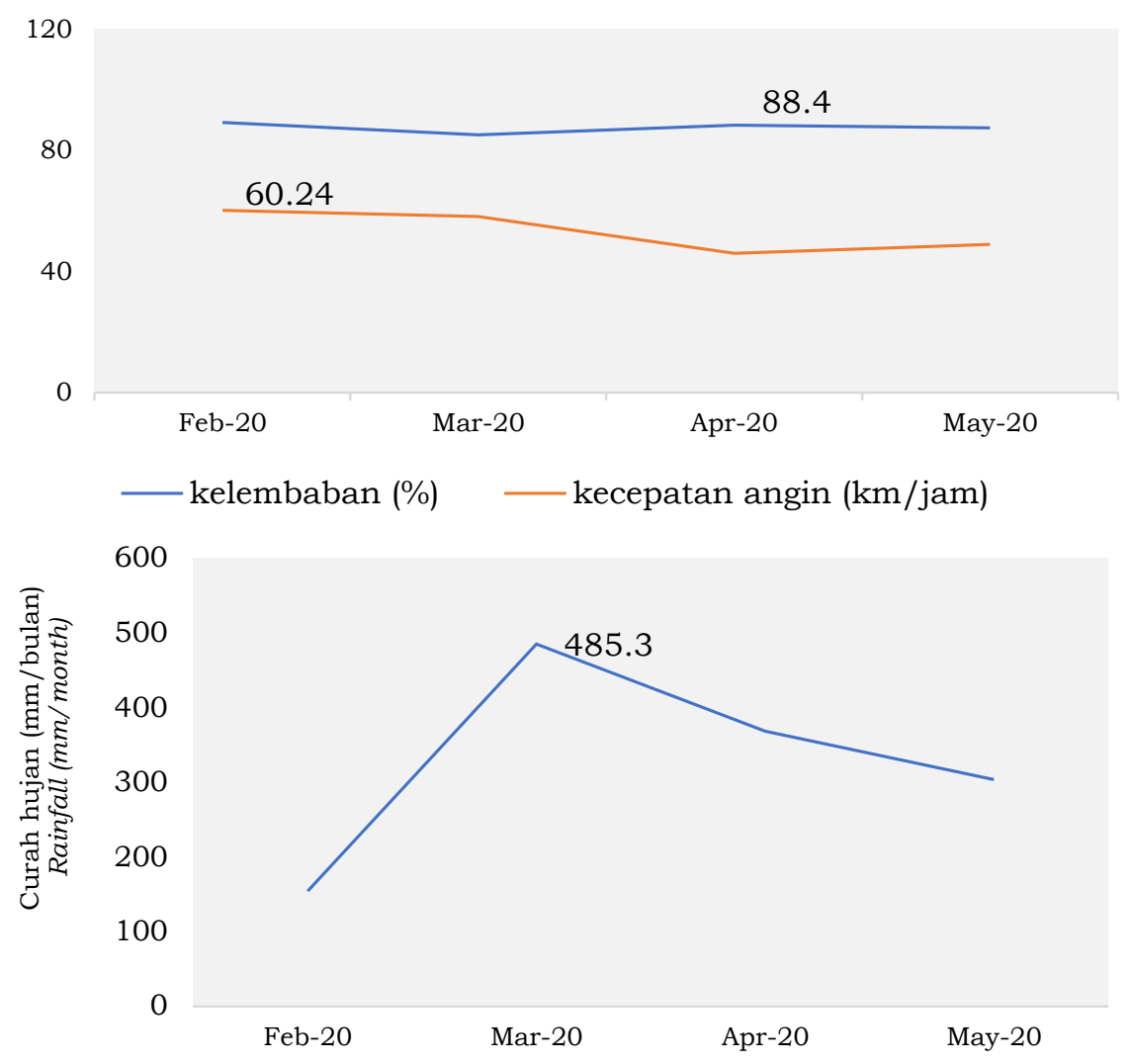

Gambar 13. Faktor iklim yang memengaruhi jumlah daun gugur Figure 13. Climate factors that affect the number of fallen leaf

\section{KESIMPULAN}

Kesimpulan yang dapat ditarik dari hasil penelitian adalah bahwa (1) aplikasi pupuk dan fungisida baik tunggal maupun kombinasinya memberikan pengaruh nyata baik terhadap kerapatan tajuk maupun produksi karet pada kondisi tanaman terserang penyakit gugur daun Pestalotiopsis, (2) aplikasi fungisida dengan cara fogging dan penyemprotan gawangan efektif mempertahankan tajuk tanaman dari serangan Pestalotiopsis, sementara pemupukan Nitrogen mempercepat pemulihan tajuk pasca serangan Pestalotiopsis, dan (3) aplikasi pupuk ektra $\mathrm{N}, \mathrm{K}$ dan kombinasinya juga meningkatkan kerapatan tajuk dan produksi karet.

\section{DAFTAR PUSTAKA}

Abdulrachman, S.Y. (2001). Pengaruh kombinasi pupuk kalium terhadap intensitas penyakit bercak daun cokelat dan bergaris pada padi. Jurnal Fitopatologi Indonesia, 5(1), 15.

Bailey, J.A., \& Jeger, M.J. (1992). Colletotrichum: Biology, Pathology and Control. UK: British Society for Plant Pathology.

Bhat, Z.A., Ahangar, M.A., Sanghera, G.S., \& Mubarak, T. (2013). Effect of cultivar, fungicide spray and nitrogen fertilization on management of rice blast under temperate ecosystem. International Journal of Science, Environment and Technology, 2(3), 410-415. 
Brady, N.C., \& Weil, R.R. (2002). The Nature and Properties of Soils. New Jersey, USA: Upper Saddle River.

Budiman, A. (1997). Pengaruh kombinasi perlakuan pupuk urea dengan fungisida untuk menanggulangi penyakit GDK pada beberapa klon karet. Laporan hasil penelitian Sembawa, Indonesia: Balai Penelitian Sembawa.

Budiman, A., \& Ben, F.A. (2001). Pengaruh kombinasi perlakuan pupuk dan fungisida untuk menanggulangi penyakit daun Colletotrichum pada beberapa klon karet. Prosiding Seminar Nasional Teknologi Pertanian Spesifik Lokasi Ekoregional Sumatera-Jawa (p. 456462). Bogor, Indoensia: Pusat Penelitian Sosial Ekonomi Pertanian.

Burhanudin, \& Nurmansyah. (2010). Pengaruh pemberian pupuk kandang dan kapur tehadap pertumbuhan dan produksi nilam pada tanah podsolik merah kuning. Buletin Penelitian Tanaman Rempah dan Obat, 21(2), 138-144. http://dx.doi.org/10.21082/bullittr o.v2 1 n2.2010.\% 25 p

Chamorro, M., Aguado, A., \& Santos, B.D. (2016). First report of root and crown rot caused by Pestalotiopsis clavispora (Neopestalotiopsis clavispora) on strawberry in Spain. Plant Disease, 100(7), 1495. https://doi.org/10.1094/PDIS-1115-1308-PDN

Dordas, C. (2009). Role of nutrients in controlling plant diseases in sustainable agriculture: a review. Agron Sustain Dev, 28, 33-46. https://doi.org/ 10.1051/agro:2007 051

Espinoza, J.G., Briceno, E.X., Keith, L.M., \& Latorre, B.A. (2008). Canker and Twig Dieback of blueberry caused by Pestalotiopsis spp. and a Truncatella $s p$. in Chile. Plant Disease, 92(10), 1407-1414. http://dx.doi.org/ 10.1094/PDIS-92-10-1407
Fahmi, A., Utami, S.N.H., \& Radjagukguk, B. (2010). Pengaruh interaksi hara nitrogen dan fosfor terhadap pertumbuhan tanaman jagung (Zea mays L) pada tanah regosol dan latosol. Berita Biologi, 10(3), 297-304. http://dx.doi.org/10.14203 /beritabiologi.v10i3.744

Febbiyanti, T.R., \& Fairuzah, Z. (2019). Identifikasi penyebab kejadian luar biasa penyakit gugur daun karet di Indonesia. Jurnal Penelitian Karet, 37(2), 193 - 206. Doi : https:// doi.org/10.22302/ppk.jpk.v37i2.61 6

Gao X, Zhang S, Zhao X, Wu Q (2018) Potassium-induced plant resistance against soybean cyst nematode via root exudation of phenolic acids and plant pathogen-related genes. PLoS ONE 13 (7): e 0200903 . https://doi.org/10.1371/journal. pone.0200903

Georgopoulos. (1982). Fungicide Resistance in Crop Protection. Wageningen, Netherland: Center for Agricultural Publishing and Documentation,.

Gonzalez, P., Alaniz, S., Montelongo, M.J., Rauduviniche, L., Rebellato, J.E., Silvera-Perez, E., \& Mondino, P. (2012). First report of Pestalotiopsis clavispora causing dieback on blueberry in Uruguay. Plant Disease, 96(6), 914. https://doi.org/ 10.1094/PDIS12-11-1070-PDN

Hashim, I., Radziah, N.Z., \& Sivanadyan, K. (1996). Management strategies of Corynespora leaf fall with fungicides and cultural practices. Workshop on Corynespora Leaf Fall of Hevea Rubber (p. 177-193). Medan, Indonesia: Indonesian Rubber Research Institute.

Hu, H.L., Jeewon, R., Zhou, D.Q., \& Hyde, K.D. (2007). Phylogenetic diversity of endophytic Pestalotiopsis species in Pinus armandii and Ribes spp: evidence from rDNA and $\beta$-tubulin gene phylogenies. Fungal Diversity, 24, 1-22. 
Kalay, A.M., Aneke, F.L., Talahaturuson, A., Sangadji, S., \& Manuhutu, L.S. (2017). Penggunaan pupuk hayati dan pupuk NPK untuk menekan penyakit layu dan meningkatkan pertumbuhan dan hasil tanaman kacang panjang (Vigna sinencis L.). Agrologia, 6(1), $11-18$. http://dx.doi.org/10.30598/a.v6i1. 175

Kusnanta, M.A. (2005). Identifikasi dan pengendalian penyakit karat palsu pada tanaman nilam (Pogostemon cablin Benth) dengan fungisida. [Tesis]. Yogyakarta, Indonesia: Universitas Gadjah Mada.

Lim, T.M. (1974). Enhancing post-wintering tree vigour for avoiding Oidium secondary leaf fall on Hevea. Proc. Rubb. Res. Inst. Malaya Pltr's Conf.1974 (p. 178-187), Kuala Lumpur, Malaysia : RRIM.

Lingga, P. (1989). Petunjuk Penggunaan Pupuk. Jakarta, Indonesia: Penebar Swadaya.

Maharachchikumbura, S.S.N., Guo, L.D., Chukeatirote, E., Bahkali, A.H., \& $\mathrm{H}$ y d e, K. D. $\left(\begin{array}{llll}2 & 0 & 1 & 1\end{array}\right)$. Pestalotiopsis-morphology, phylogeny, biochemistry and diversity. Fungal Diversity, 50, 167-187. https://doi.org / 10.1007/ s13225-011-0125-x

Maharachchikumbura, S.S.N., Chukeatirote, E., Guo, L.D., Crous, P.W., McKenzie, E.H.C., \& Hyde, K.D. (2012). Pestalotiopsis species associated with Camellia sinensis (tea). Mycotaxon, 123, 47-61. https://doi.org/10.5248/123.47

Maharachchikumbura, S.S.N., Hyde, K.D., Groenawald, J.Z., Xu, J., \& Crous, P.W. (2014). Pestalotiopsis revisited. Studies in Mycology, 79, 121-186. https://doi.org/10.1016/j.simyco.2 014.09.005
Pawirosoemardjo, S. (1984). Beberapa aspek hubungan pathogen-inang dalam penyakit gugur daun Colletotrichum pada Hevea brasiliensis Muell Arg. [Disertasi]. Bogor, Indonesia: Institut Pertanian Bogor.

Pawirosoemardjo, S. (1995). Penyakit gugur daun Colletotrichum pada karet di Indonesia: masalah, biologi patogen, perkembangan penyakit, dan cara pengendaliannya. Risalah Konggres Nasional XII dan Seminar Ilmiah Perhimpunan Fitopatologi Indonesia (p. 858-870). Yogyakarta, Indonesia: Perhimpunan Fitopatologi Indonesia.

Pawirosoemardjo, S. (2004). Manajemen pengendalian penyakit penting dalam upaya mengamankan target produksi karet nasional tahun 2020. Di dalam : Aron, S., Arief, B., Heru, S., Thomas, Mudji, L., Anang, G. Pertemuan Teknis "Strategi Pengelolaan Penyakit Tanaman Karet untuk Mempertahankan Potensi Produksi Mendukung Indistri Perkaretan Indonesia Tahun 2020. Palembang, Indonesia: Balai Penelitian Sembawa.

Rajalakshmy, U.K., Potty, S.N., K o y hand a r a m a n, R., \& Karthikakutty, A. (1979). Influence of nutrition disease incidebee-glass house experiment to study the effect of N, P. in konf. leaf spot disease of rubber caused by Corynespora cassiicola. Proceedings Placrosym-II Ootacamund Indian Society for Plantation Crops. India: CPCRI.

Rajalakshmy, V.R., \& Kothandaraman, R. (1996). Current status of Corynespora leaf fall in India: The occurrence and management. Workshop on Corynespora Leaf Fall of Hevea Rubber (p. 37-46). Medan, Indonesia: Indonesian Rubber Research Institute. 
Saufe A.A. Sulaiman Z.,Adekunle S.M., Samad MYA, Yusoof M.M. (2018). Influence of Different Rates of Nitrogen (N) and Phosphorus (P) Fertilizers on Growth and nutrient use efficiency of rubber (Hevea brasiliensis). European Journal of Engineering Research and Science Vol. 3(3): $53-57$.

Situmorang, A., \& Budiman, A. (1985). Corynespora cassiicola (Berk \& Curt) Wei penyebab penyakit gugur daun pada karet. Kumpulan makalah, artikel, dan catatan Penyakit gugur daun pada karet (Corynespora cassicola). Bogor, Indonesia: Balai Penelitian Perkebunan Bogor.

Situmorang, A. (1989). Pengaruh fungisida mankozeb dan pupuk urea terhadap perkembangan penyakit gugur daun Colletotrichum dan pertumbuhan tanaman di pembibitan karet. Buletin Perkebunan Rakyat, 5(1), 44-51.

Situmorang, A. (1995). Penerapan pengendalian penyakit cendawan akar putih di Jambi. Laporan hasil penelitian. Sembawa, Indonesia: Balai Penelitian Sembawa Pusat Penelitian Karet.

Situmorang, A., \& Sihombing, H. (1995). Pengaruh pemberian dolomit dan peningkatan dosis pupuk $\mathrm{N}, \mathrm{P}$ dan $\mathrm{K}$ terhadap perkembangan penyakit gugur daun Colletotrichum pada entres karet klon PR 300. Prosiding Seminar Pengendalian Organisme Pengganggu Tumbuhan dalam Mendukung Pembangunan Daerah Sumatera Selatan (p. 42-48). Palembang, Indonesia: Fakultas Pertanian Universitas Palembang dan Perhimpunan Fitopatologi Komisariat Sumatera Selatan.

Steineck, O., \& Haeder, H.E. (1978). The effect of potassium on growth and yield components of plants, in potassium research-review and trends. International Potash Institute.
Suryadi, Y. (1995). Pengaruh kalium dan mulsa terhadap penyakit hawar daun bakteri (Pseudomonas syringae pv glycinea). Risalah Kongres Nasional XII dan Seminar Ilmiah Perhimpunan Fitopatologi Indonesia (p. 249-254). Yogyakarta, Indonesia: Perhimpunan Fitopatologi Indonesia.

Suwarto, Pawirosoemardjo, S., \& Sinulingga, W. (1986). Respon klon karet anjuran terhadap penyakit gugur daun Corynespora di Indonesia. Prosiding Lokakarya Penyakit Gugur Daun Corynespora pada Tanaman Karet (p. 29-36). Medan, Indonesia: Pusat Penelitian Karet.

Tajuddin. (1981). Major nutrient- their role and deficiency symptoms. RRIM Training Manual on Soil, Soil Management and Nutrition of Hevea (p. 87-92). Kuala Lumpur, Malaysia: Rubber Research Intitute of Malaysia

Thomas., Budiman, A., \& Hidayati, U. (2003). Status hara kalium dengan serangan penyakit daun Corynespora pada klon RRIM 600. Warta Perkaretan, 22(1), 24-31.

Tisdale, S., \& Nelson, W. (1975). Soil Fertility and Fertilizer. London, UK: McMillan Publish Co.

Untung, K. (2001). Pengantar Pengelolaan Hama Terpadu. Yogyakarta, Indonesia: Gadjah Mada University Press.

Valencia, A.L., Torres, R., \& Latorre, B.A. (2011). First report of Pestalotiopsis clavispora and Pestalotiopsis spp. causing postharveststem end rot of avocado in Chile. Plant Disease, 95(4), 492. https: / / doi.org/ 10.1094/PDIS-11-10-0844

Veresoglou, S.D., Barto E.K., Manexes G., Rillig M.C. (2013). Fertilization affects severity of disease caused by fungal plant pathogens. Plant Pathology, 62, 961 -969. Doi: 10.1111/ppa.12014 
Wang M., Zheng Q., Shen Q., Guo S., (2013). The critical role of potassium in plant stress. Int. J. Mol. Sci., 14(14), 7370 7390. doi: $10.3390 /$ ijms 14047370

Wijaya T., Ardika R., Saputra J. (2014). The effect of omission fertilizer application on rubber yield of PB 260. Current Agriculture Research Journal, Vol. 2(2), 68-72 .
Wilmer, C.M. (1983). Stomata. London, UK: Longman Group Ltd. 